41 Johnson J, Kuskowski M, Wilt T. Systematic review: Antimicrobial urinary catheters to prevent catheter-associated urinary tract infection in hospitalized patients. Annals Int Med 2006; 144: 116-26.

42 Apisarnthanarak A. Initial inappropriate urinary catheters use in a tertiary-care center: incidence, risk factors, and outcomes. Am J Infection Control 2007; 35: 594-99.

43 Refthomas M. Diagnosis, Prevention and Treatment of Catheter-Associated Urinary Tract Infection in Adults: 2009 International Clinical
Practice Guidelines from the Infectious Diseases Society of America. Clin Infectious Dis 2010; 50: 625-63.

44 Fader M, Pettersson L, Brooks R. A multicentre comparative evaluation of catheter valves. $\mathrm{Br} \mathrm{J}$ Nursing 1997; 6: 359-67.

45 Sabbuba NA, Stickler DJ, Long MJ, Dong Z, Short TD, Feneley RJ. Does the valve regulated release of urine from the bladder decrease encrustation and blockage of indwelling catheters by crystalline proteus mirabilis biofilms? J Urol 2005; 173: 262-66.

\title{
CORRIGENDUM
}

\section{Continence aids in the management of urinary incontinence - CORRIGENDUM}

Browning J., Zaheer Z., Orzechowska A. and Mistri A.

doi:10.1017/S0959259811000244, Published by Cambridge University Press,

Published online 5 January 2012.

The legend to Figure 13 on page 11 of the above paper (Browning et al., 2012) was incomplete. The full legend is as follows:

Figure 13. Examples of washable incontinence underwear and disposable products (reproduced with permission from P\&S Healthcare Ltd and SCA (TENA) Hygiene Products)

\section{Reference}

Browning J, Zaheer Z, Orzechowska A, Mistri A. (2012). Continence aids in the management of urinary incontinence. Reviews in Clinical Gerontology. Published online 5 January 2012. 